\title{
Performance of Asiatic and Oriental Lilium Hybrids under Lower Altitudes of Nagaland
}

\author{
A. Thirugnanavel ${ }^{1 *}$, Bidyut C. Deka ${ }^{2}$, Naksungla Walling ${ }^{3}$ and Lily Rangnamei ${ }^{4}$ \\ ${ }^{1}$ Central Citrus Research Institute, Amravati Road, Nagpur - 440033, Maharashtra, India \\ ${ }^{2}$ ICAR Agricultural Technology Application Research Institute, Umiam, \\ Barapani -793103, Meghalaya, India \\ ${ }^{3}$ School of Agricultural Sciences and Rural Development, Nagaland University, \\ Nagaland, India \\ ${ }^{4}$ SMS (Horticulture), Krishi Vigyan Kendra, ICAR Manipur Centre, Lamphelpat, \\ Imphal West, 795 004, Manipur, India \\ *Corresponding author
}

\begin{abstract}
A B S T R A C T
Keywords

Lilium, Asiatic hybrids, Oriental hybrids, Growth, Floral characters

Article Info

\section{Accepted:}

17 March 2019

Available Online:

10 April 2019

An experiment was conducted during 2011-12 to evaluate the lilium hybrids at ICAR Research Complex for NEH Region, Nagaland Centre, Nagaland. Three Asiatic lilium hybrids viz., Sulpice, Brunello, Barasso and three Oriental hybrids viz., Acapulco, Lamacha and Carmina were evaluated for their growth and yield characters. The results revealed that there was significant difference in growth, floral and flower quality characters. The data revealed that Barasso recorded maximum Plant height $(68.75 \mathrm{~cm})$, stem diameter $(0.65 \mathrm{~cm})$, whereas Brunello recorded maximum numbers of leaves $(81.80)$ and took minimum days for bud burst (2.36 days), and bud emergence (27.85 days). Acapulco recorded maximum bud length $(14.94 \mathrm{~cm})$ and took minimum days for flowering (75.15 days). Lamacha recorded maximum bud diameter $(3.40 \mathrm{~cm}$ ) and diameter of flower $(26.20 \mathrm{~cm})$ and Carmina recorded maximum number of buds (3.85). Sulpice took less numbers of days to come to full bloom (3.73 days). Based on the study, the hybrids viz., Brunello, Barasso, and Lamacha were more suitable for lower altitudes of Nagaland in terms of growth, floral and flower quality traits.
\end{abstract}

\section{Introduction}

The genus Lilium, one of the most important bulbous plants, has more than 90 species, which are classified into different sections (Asano, 1989 and Smyth et al., 1989). It ranks $6^{\text {th }}$ among the top ten cut flowers in international trade, has beautiful, attractive and bright flowers with comparative long vase life. It fetches relatively higher price in the market than other commercial flowers. Lilies are attractive ornamental plants with variety of colours, fragrance and adaptability to several environmental conditions (Bahr and 
Compton 2004). They are widely used in the floral industry as cut flower and potted plant. In recent years much improved forms and colors in varieties have being developed. There are number of hybrids in various lilium species available and every new cultivar is introduced for commercial forcing as cut flower and pot plants. The floriculture sector in India is steadily growing with total export of 22,485.21 MT worth Rs. 455.90 crores in 2013-14 (APEDA, 2015). The floriculture crops have been cultivated in an area of about 2.54 lakh hectares with production of 20.47 lakh $\mathrm{mt}$ of loose flowers and 81,156 lakh stems of cut flowers during 2015-16 (NHB, 2017). Northeast India is best endowed with climatic conditions which support the cultivation of variety of cut flowers (APEDA, 2015).

Nagaland, popularly called as "Land of Festivals" requires plenty of cut flowers particularly winter season. The cut flower industry is steadily growing in the state and the cut flowers have been cultivated in an area of about 8.85 ha with the production of 7102000 stems. Of which, lilium is cultivated in an area of about 2.13 ha with production of 1276800 stems and the productivity is 60 stems $/ \mathrm{m}^{2}$ during 2014-15 (Statistical hand book of Nagaland, 2015). It is mainly cultivated in Kohima, Mokokchung, Wokha and Phek districts of Nagaland. The growth and development of lilium is governed by its genetic makeup and the environmental factors of the growing region and various management practices. The lilium cultivation is mainly restricted to cooler areas of Nagaland. Due to the efforts of researchers, the cultivation of lilium is possible in plains with the development of new hybrids. Therefore, the present study was undertaken to evaluate the lilium hybrids for growth and yield under low altitude conditions of Nagaland so that the farmer's could use the appropriate cultivar for cultivation in lower altitudes to gain better income.

\section{Materials and Methods}

The present experiment was carried out in ICAR Research Complex for NEH Region, Nagaland Centre, Jharnapani during 2011-12 to evaluate three Asiatic lilium hybrids viz., Sulpice, Brunello, Barasso and three Oriental hybrids viz., Acapulco, Lamacha and Carmina for their growth and yield characters under 50 per cent shade net (Fig. 1 and 2). The experimental field is situated at $25^{\circ} 45^{\prime} 24^{\prime \prime} \mathrm{N}$ latitude, 93'50'26" E longitude and an altitude of $281 \mathrm{~m} \mathrm{msl}$. The experiment was laid out in Randomized Block Design with 4 replications. The lilium bulbs were planted at $30 \times 30 \mathrm{~cm}$ spacing. The standard package of practices was followed for all the hybrids throughout the experiment. Eleven traits viz., plant height $(\mathrm{cm})$, number of leaves, days taken for bud emergence (days), number of buds, days taken for flowering, length of bud $(\mathrm{cm})$, diameter of bud $(\mathrm{cm})$, diameter of stem $(\mathrm{cm})$, diameter of flower $(\mathrm{cm})$, days taken for bud burst (days ), and days taken for full bloom were recorded. The data were statistically analyzed for analysis of variance using HAU OPSTAT statistical software packages (Sheoran et al., 1988).

\section{Results and Discussion}

The analysis of data revealed significant variations in growth and floral characters of different hybrids and the results were presented in table 1 . The data revealed that there were significance difference in plant height $(\mathrm{cm})$, number of leaves, stem diameter (cm), days taken for bud emergence, and no. of buds per plant. It was observed that the Asiatic hybrids were vigourous than Oriental hybrids. The highest plant height was found in Barasso $(68.75 \mathrm{~cm})$ followed by sulpice $(54.50 \mathrm{~cm})$, while it was minimum in Carmina $(39.85 \mathrm{~cm})$. The maximum number of leaves was found in Brunello (81.80) and the minimum number of leaves was found in 
Carmina (39.85). The maximum stem diameter of $0.65 \mathrm{~cm}$ was recorded by Barasso and the minimum stem diameter of $0.52 \mathrm{~cm}$ was recorded by Sulphice and Brunello. The variation in vegetative growth may be due to growth rate, growing environment and genetic makeup of hybrids (Mishra, 1997) and similar observations on vegetative characters were earlier reported by (Vidalie et al., 1985; Dhinam, 2003; Pandey et al., 2008 and Negi et al., 2016). Brunello took minimum of 27.85 days for bud emergence and Carmina took maximum of 45.60 days for bud emergence. The maximum number of buds per plant was recorded by Carmina (3.85) which was closely followed by Brunello (3.80). The minimum number of buds per plant was recorded by Barasso (1.80). These results are in close conformation with the result obtained by Dhiman (2003), Kumar et al., (2011) and Negi et al., (2016). The variation in floral characters might be due to genetic difference of genotypes and are governed by the genetic makeup of the plant. Superiority of some genotypes over other genotypes was also reported by several works in gladiolus (Arora and Khanna, 1985; Pant and Lal, 1991).

The data of floral and its quality characters revealed that significant variations were observed among the hybrids and the results were presented in the table 2 . The maximum days taken for bud burst after bud emergence was recorded by Barasso (6.31 days) and the minimum days for bud burst was recorded by Brunello (2.36 days) which was closely followed by Sulpice (2.64 days).

Table.1 Growth characters of lilium hybrids under lower altitudes of Nagaland

\begin{tabular}{|l|c|l|l|c|c|}
\hline Cultivar & $\begin{array}{l}\text { Plant height } \\
(\mathrm{cm})\end{array}$ & $\begin{array}{l}\text { Number of } \\
\text { leaves }\end{array}$ & $\begin{array}{l}\text { Diameter of } \\
\text { stem }(\mathrm{cm})\end{array}$ & $\begin{array}{l}\text { Days taken for bud } \\
\text { emergence (days) }\end{array}$ & $\begin{array}{l}\text { Number } \\
\text { of buds }\end{array}$ \\
\hline Sulpice & 54.50 & 66.85 & 0.52 & 34.05 & 2.10 \\
\hline Brunello & 47.00 & 81.80 & 0.52 & 27.85 & 3.80 \\
\hline Barasso & 68.75 & 47.90 & 0.65 & 43.50 & 1.80 \\
\hline Acauplco & 52.05 & 30.15 & 0.61 & 40.20 & 2.10 \\
\hline Lamacha & 42.60 & 28.00 & 0.61 & 35.55 & 2.55 \\
\hline Carmina & 39.85 & 35.20 & 0.61 & 45.60 & 3.85 \\
\hline CD at 5\% & 7.33 & 4.79 & 0.03 & 4.85 & 0.47 \\
\hline
\end{tabular}

Table.2 Flowering and flower quality of lilium hybrids under lower altitudes of Nagaland

\begin{tabular}{|l|l|l|l|l|l|l|}
\hline Cultivar & $\begin{array}{l}\text { Days taken for } \\
\text { bud burst }\end{array}$ & $\begin{array}{l}\text { Days taken } \\
\text { for full bloom } \\
\text { (days) }\end{array}$ & $\begin{array}{l}\text { Days } \\
\text { taken for } \\
\text { (days) }\end{array}$ & $\begin{array}{l}\text { Length of } \\
\text { flowering }\end{array}$ & $\begin{array}{l}\text { Diameter } \\
\text { of bud }\end{array}$ & $\begin{array}{l}\text { Diameter } \\
\text { of flower } \\
\text { (cm) }\end{array}$ \\
\hline Sulpice & 2.64 & 3.73 & 81.10 & 9.56 & 2.85 & 23.51 \\
\hline Brunello & 2.36 & 3.75 & 78.15 & 7.13 & 2.08 & 18.14 \\
\hline Barasso & 6.31 & 5.55 & 82.50 & 10.38 & 2.72 & 20.51 \\
\hline Acauplco & 5.34 & 6.35 & 75.15 & 14.94 & 3.08 & 25.92 \\
\hline Lamacha & 3.16 & 4.51 & 117.27 & 11.51 & 3.40 & 26.20 \\
\hline Carmina & 3.74 & 4.23 & 118.45 & 11.51 & 2.58 & 24.41 \\
\hline CD at 5\% & 0.06 & 1.28 & 4.85 & 0.13 & 0.35 & 2.44 \\
\hline
\end{tabular}


Fig.1\&2 Evaluation of lilium hybrids
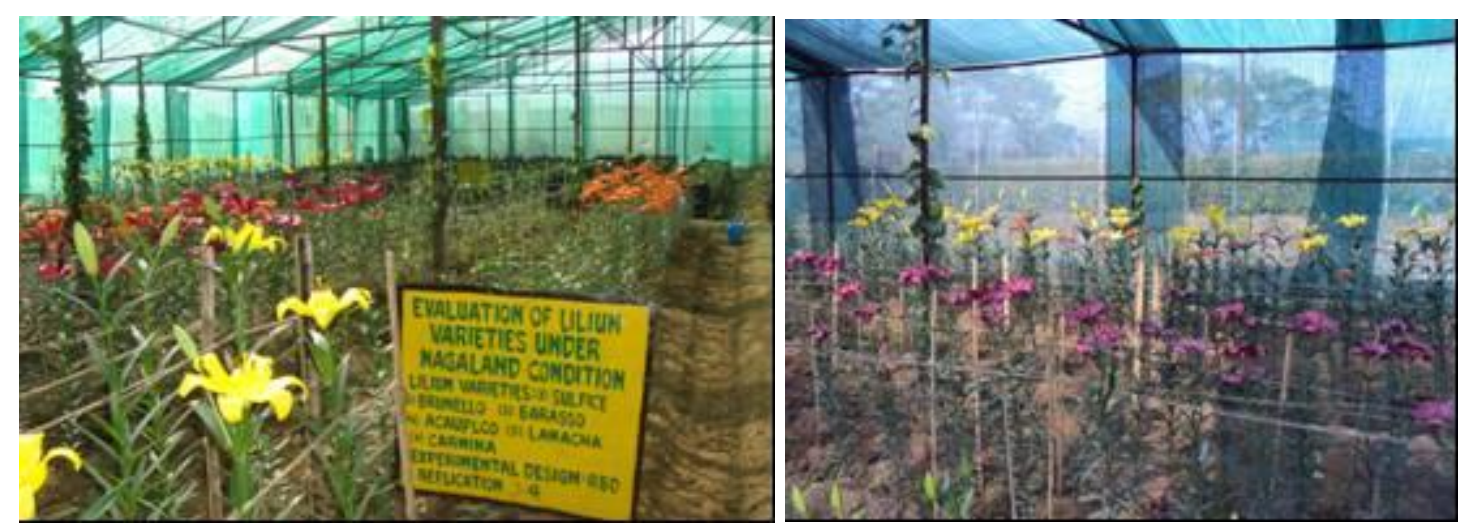

Acauplco took maximum days for full bloom after bud burst (6.35 days) and Sulpice took minimum days for full bloom (3.73 days) which was closely followed by Brunello (3.75 days). Acauplco (75.15 days) and Brunello (78.15 days) flowered early whereas Lamcha (117.27 days) and Carmina (118.45 days) flowered late. The maximum bud length was recorded in Acauplco $(14.94 \mathrm{~cm})$ and the minimum bud length was recorded in Brunello $(7.13 \mathrm{~cm})$. Lamacha recorded the maximum bud diameter $(3.40 \mathrm{~cm})$ whereas Brunello recorded the minimum bud diameter $(2.08 \mathrm{~cm})$. The maximum diameter of flower was recorded by Lamacha $(26.20 \mathrm{~cm})$ which was closely followed by Acauplco $(25.92 \mathrm{~cm})$ and the minimum flower diameter was recorded by Brunello $(18.14 \mathrm{~cm})$. The differences in floral and quality characters might be due to genetic difference of genotypes and are governed by the genetic makeup of the plant. Similar kind of variation in floral characters in lilium was earlier reported by Dhinam (2003), Kumar et al., (2011), Negi et al., (2014) and Negi et al., (2016). Based on the findings, the hybrids, viz., Brunello, Barasso, and Lamacha were performed well under lower altitude conditions of Nagaland.

\section{Acknowledgement}

The authours are highly grateful to Director, ICAR Research Complex for NEH Region,
Umiam, Barapani, Meghalaya for technical guidance and Mission Director, Mission for Integrated Development of Horticulture in Northeast for financial assistance.

\section{References}

Anonymous. 2015. Agricultural Produce Processing and Export Development Authority (APEDA). Export Status in India. Ministry of Commerce and Industry, New Delhi.

Anonymous. 2017. Indian Horticulture Database. National Horticulture Board, Ministry of Agriculture, Government of India, Gurgaon, Haryana.

Arora, J.S. and Khanna, K.1985. Evaluation of gladiolus cultivars. J. Research, PAU 22(4): 655-662

Asano, Y. 1989. Lilium L., In: Y. Tsukamoto (Ed.), The Grand Dictionary of Horticulture, vol. 5, Syogakukan, Tokyo, 1989, pp. 198-209 (in Japanese).

Attavar, M. and Bhatt, N.K. 1995. Export oriented floriculture: Growth perceptions; 81-91 (Prospects of floriculture in India by G.L. Kaul and N. K. Dadlani). Min. of Agri., New Delhi.

Bahr L. R. and Compton, M.E. 2004. Competence for in vitro bulb regeneration among eight lilium 
genotypes. HortScience, 39(1): 127129.

Dhiman, M.R., 2003. Evaluation of lillium hybrids under Kullu conditions. J. Orn. Hort., 6(2): 154-155.

Kumar, R., Patel, V., Verma, D., Bidyut C. Singh and Sindhu, S. 2011. Evaluation of Asiatic lilium under subtropical mid hills of Meghalaya. Advance Research Journal of Crop Improvement, 2(2) 257259.

Kumar, R. and Yadav, D.S. 2003. Evaluation of gerbera for NEH region. J. Orn. Hort., 691: 69-70.

Mishra, H. P. 1997. Performance of gladiolus genotypes under calcareous soil for North-Bihar. Indian J. Hort., 14(1): 77 92.

Pandey, R. K., Dogra Sheetal, Sharma, J. P. and Jamwal Shivani. 2008. Evaluation of Asiatic hybrid lily cultivars under subtropical conditions of Jammu region. Journal of Plant Science Research, 24(2): 213-214.

Pant, C.C. and Lal, S.D. 1991.Genetic variability in gladiolus. Prog. Hort., 23(1): 1-4.

Reshma Negi, Kumud Jarial, RS Jarial, Sunil Kumar and SR Dhiman. 2016.
Evaluation of lilium cultivars for suitability under low hill conditions of Himachal Pradesh. Journal of Hill Agriculture 7(2): 201-203

Reshma Negi, Sunil Kumar, and S. R. Dhiman. 2014. Evaluation of lilium (Lilium Spp.) cultivars for low hills of Himachal Pradesh. Ind. J. Sci. Res. and Tech., 2(4):8-10

Sheikh. M. Q. and Jhon, A. Q. 2005. Response of planting dates and genotypes on vegetative and floral characters in gladiolus. J. Orn. Hort., 8(3): 219-221.

Singh, M.K., Kumar, S. and Ram. R. 2008. Effect of nitrogen and potassium on growth, flowering and bulb production in Asiatic hybrid lily cv. Novecento. J. Orn. Hort., 11(1):45-48.

Smyth, D.R., Kongsuwan, F. K., and Wisudharomn. 1989. A survey of Cband patterns in chromosomes of Lilium (Liliaceae), Plant Syst Evol., 163: 53-69

Vidalie Hi, Mi Laffaire, Rivere, L.M and Charperitier, S. 1985. First result on the performance of gerbera cultivativated on rock wool. Revue Horticole, 262: 1318.

\section{How to cite this article:}

Thirugnanavel, A., Bidyut C. Deka, Naksungla Walling and Lily Rangnamei. 2019. Performance of Asiatic and Oriental Lilium Hybrids under Lower Altitudes of Nagaland. Int.J.Curr.Microbiol.App.Sci. 8(04): 2242-2246. doi: https://doi.org/10.20546/ijcmas.2019.804.261 